\title{
REPRODUCTIVE CYCLE OF THE FEMALE FIVE-STRIPED INDIAN PALM SQUIRREL, FUNAMBULUS PENNANTI (WROUGHTON)
}

\author{
PUSHPA SETH AND M. R. N. PRASAD \\ Department of Zoology, University of Delhi, Delhi-7, India \\ (Received 15th August 1968)
}

\begin{abstract}
Summary. The five-striped Indian palm squirrel, Funambulus pennanti, is a seasonal breeder from January to August. Mature females are sexually quiescent from September to December; recrudescence of the gonad starts in late December. The palm squirrel is a reflex ovulator. A mature female may produce two litters of approximately three young each in one breeding season. The period of suckling is 6 weeks. Mature females experience a short period of post-lactational anoestrus during the breeding season prior to the onset of second oestrus. The role of exteroceptive factors in regulating the reproductive cycle of the palm squirrel is discussed.
\end{abstract}

\section{INTRODUGTION}

The female reproductive cycles of a few squirrels have been described: Sciurus carolinensis (Deanesly \& Parkes, 1933; Shorten, 1951), Citellus tridecemlineatus (Foster, 1934), C. beecheyi (Tomich, 1962) and C. beldingi and C. lateralis (McKeever, 1963, 1966). The only report on a female Indian palm squirrel is by Prasad (1951) on Funambulus palmarum of South India.

The striped palm squirrels of the genus Funambulus occur in India and Ceylon. Funambulus pennanti, included in the subgenus Prasadsciurus, is the common five-striped palm squirrel of northern India (Moore \& Tate, 1965). It is arboreal in nature and lives in holes of tree trunks close to human habitation. These squirrels do not hibernate or aestivate and are active throughout the year despite high summer temperatures (maximum 44 to $46^{\circ} \mathrm{C}$ ) and low winter temperatures (minimum 0 to $3^{\circ} \mathrm{C}$ ).

\section{MATERIALS AND METHODS}

Three hundred squirrels used in this study were trapped alive in Delhi over a period of 2 years from May 1963 to April 1965. They were obtained from the wild population and their body weights were recorded to the nearest gram at autopsy, which was carried out within $24 \mathrm{hr}$ of trapping. Vaginal smears were examined for spermatozoa. The ovaries, uterus, adrenals and thyroids were 
quickly removed, weighed and fixed in Bouin's fluid for histological study. The secretory activity of the mammary glands was also noted.

Sections of the ovary, uterus and vagina were cut at $7 \mu$ and stained with haematoxylin and eosin.

The number of embryo sites was recorded in pregnant squirrels and the size of the implantation site was measured to determine the approximate stage of pregnancy.

The data obtained were analysed statistically.

\section{OBSERVATIONS AND DISCUSSION}

The characterization of a squirrel of unknown reproductive history based on gross as well as histological reproductive criteria is indicated schematically in the flow-sheet.

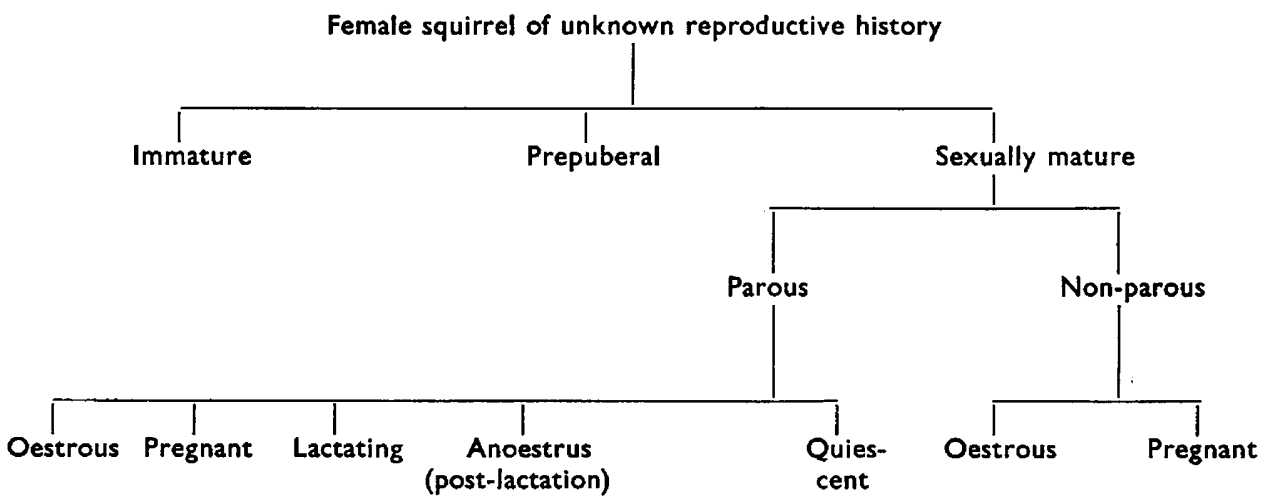

By gross examination, it is possible to distinguish the following groups of squirrels:

1. Immature females-mammary glands undeveloped, vagina imperforate, body weight ranging between 60 and $90 \mathrm{~g}$.

2. Mature females-two pairs of well-developed mammary glands; vulva swollen and vagina open.

3. Pregnant females-embryos can be detected by palpating the abdomen; mammary glands are well-developed and vulva large.

4. Lactating females-milk can be expressed from well-developed mammary glands.

5. Mature females in quiescence-mammary glands are regressed with small blackened nipples, and small vulva; placental scars in the uterus.

On microscopic examination of sections of the reproductive tract, particularly of the ovary, further distinctions can be made (a) between parous and nonparous mature squirrels, and (b) between sexually active females in oestrus and sexually inactive squirrels in anoestrus during the breeding period.

Vaginal smears, taken regularly for 30-day periods during the breeding season from squirrels maintained in the laboratory, failed to show the cyclical change seen in smears of the laboratory rat. Similarly, no pattern was noted in smears obtained from field squirrels at autopsy. A majority of non-pregnant, 
mature squirrels (parous and non-parous) collected in January and February showed the type of vaginal smear seen characteristically at late pro-oestrus in rats. The smear was thick, clumped and opaque consisting of nucleated epithelial cells and cornified cells; spermatozoa were also observed in a few of these smears. The vulva was large and swollen while the vaginal lumen was lined by five to six layers of cornified eosinophilic cells. Squirrels of this type will be referred to as the oestrous type in further discussions. In pregnant and lactating females, however, the smear pattern was indeterminate though leucocytes were seen in a few pregnant females. The vaginal lumen of parous squirrels in anoestrus or during quiescence was almost closed and it was not possible to obtain vaginal smears.

Analysis of our data indicates that the five-striped palm squirrel breeds seasonally from January to August. Young are born between March and the end of September. Mature parous females become sexually quiescent from September to December. Recrudescence of the gonads begins in late December to reach the active state in January.

No correlation was found between body weights and sexual activity during different phases of the breeding cycle. The average body weights of mature females (including non-pregnant, pregnant and lactating female squirrels) range from 110 to $130 \mathrm{~g}$. Immature squirrels weigh about 60 to $70 \mathrm{~g}$ in April when they first appear in the field, and increase to $100 \mathrm{~g}$ as they approach sexual maturity between January and March of the following year.

\section{Immature females}

Immature females occur throughout the year. Maximum numbers of immature animals are found from September to January (38 to 60\%) but only $10 \%$ and $7 \%$ of the animals trapped in March and April, respectively, are immature (Text-fig. I).

Since pregnancies occur from February until September, young are born at different times during this period; hence immature animals in various phases of growth and development are available throughout the year. Ovarian weights range between 4 and $10 \mathrm{mg}$ from April to August and level out between 6 and 7 $\mathrm{mg}$ from September till December (Tables 1 and 2). The slight, statistically insignificant decrease in ovarian weights in June and September could be due to the admixture in the collection of many immature squirrels born during the two peaks of pregnancies in March and July. With the approach of maturity from January to March, ovarian activity is enhanced, resulting in an increase in weights to prepuberal levels (9 to $13 \mathrm{mg}$ ).

In young immature females, 2 to 3 months old, the ovaries contain mainly naked oocytes and primordial oocytes surrounded by one layer of flattened epithelial cells. Interstitial tissue is not developed in such ovaries. The uterus is small and thin and uterine glands are undeveloped.

Prepuberal squirrels, 6 to 8 months old, show early stages of follicular development in a graded series from the cortex towards the medulla of the ovary (Pl. 1, Fig. 1). The oocytes of more than $50 \%$ of the primordial follicles are atretic, while atresia in vesicular follicles is mainly of the granulosa cells which become pycnotic. Interstitial cells with round nuclei but scanty cytoplasm are 
sparsely distributed among the developing follicles. Initiation of glandular activity in the uterus coincides with the differentiation of medium-sized follicles.

Ovarian follicular activity indicative of prepuberal changes occurs in December to January and leads to the onset of oestrus in January. Since the first litters are born in March, the appearance of puberal animals in oestrus for the first time in January of the following year indicates a period of immaturity of about 8 to 10 months. All immature females born at any time during the previous breeding season become sexually mature by the end of March of the

TABLE 1

AVERAGE MONTHLY WEIGHTS OF THE OVARIES OF PALM SQUIRRELS

\begin{tabular}{|c|c|c|c|c|c|c|c|c|}
\hline & \multicolumn{2}{|c|}{ Immature } & \multicolumn{2}{|c|}{$\begin{array}{l}\text { Mature, non-pregnant, } \\
\text { non-lactating }\end{array}$} & \multicolumn{2}{|c|}{ Pregnant } & \multicolumn{2}{|c|}{ Lactating } \\
\hline & $\begin{array}{l}\text { Abs. } w t \\
m g \pm S . E .\end{array}$ & $\begin{array}{c}m g / 100 g \\
b o d y w t\end{array}$ & $\begin{array}{l}A b s . w t \\
m g \pm S . E .\end{array}$ & $\begin{array}{c}m g / 100 g \\
b o d y w t\end{array}$ & $\begin{array}{l}A b s . w t \\
m g \pm S . E .\end{array}$ & $\begin{array}{l}m g / 100 g \\
\text { body wt }\end{array}$ & $\begin{array}{l}\text { Abs. } w t \\
m g \pm S . E .\end{array}$ & $\begin{array}{c}m g / 100 g \\
b o d y w t\end{array}$ \\
\hline $\begin{array}{l}\text { January } \\
\text { February } \\
\text { March } \\
\text { April } \\
\text { May } \\
\text { June } \\
\text { July } \\
\text { August } \\
\text { September } \\
\text { October } \\
\text { November } \\
\text { December }\end{array}$ & $\begin{array}{r}9.3 \pm 0.7 \\
10.8 \pm 1.8 \\
13.2 \pm 1.6 \\
4.3 \pm 0.7 \\
7.5 \pm 0.7 \\
6.3 \pm 0.4 \\
8.4 \pm 1.0 \\
10.5 \pm 3.4 \\
6.4 \pm 0.6 \\
6.7 \pm 0.9 \\
7.5 \pm 0.7 \\
6.6 \pm 0.5\end{array}$ & $\begin{array}{r}11 \cdot 2 \\
12 \cdot 5 \\
13 \cdot 0 \\
6 \cdot 7 \\
9 \cdot 6 \\
12 \cdot 1 \\
10 \cdot 8 \\
11 \cdot 8 \\
7 \cdot 4 \\
7 \cdot 5 \\
8 \cdot 2 \\
8 \cdot 0\end{array}$ & $\begin{array}{l}20.8 \pm 1.7 \\
20.9 \pm 1.4 \\
23.4 \pm 3.9 \\
19.8 \pm 2.0 \\
27.6 \pm 5.3 \\
26.1 \pm 2.8 \\
20.5 \pm 3.5 \\
19.1 \pm 2.7 \\
11.5 \pm 1.9 \\
12.5 \pm 1.6 \\
13.8 \pm 1.2 \\
15.5 \pm 1.5\end{array}$ & $\begin{array}{l}18 \cdot 3 \\
18 \cdot 4 \\
23 \cdot 0 \\
17 \cdot 6 \\
24 \cdot 7 \\
24 \cdot 2 \\
18 \cdot 3 \\
18 \cdot 1 \\
11 \cdot 1 \\
11 \cdot 0 \\
11 \cdot 4 \\
14 \cdot 3\end{array}$ & $\begin{array}{c}25 \cdot 0 \pm 3 \cdot 1 \\
28 \cdot 4 \pm 2 \cdot 8 \\
23 \cdot 5 \pm 1 \cdot 4 \\
30 \cdot 1 \pm 2 \cdot 8 \\
17 \cdot 5 \\
26 \cdot 5 \pm 2 \cdot 3 \\
36 \cdot 4 \pm 6 \cdot 3 \\
34 \cdot 0 \\
- \\
-\end{array}$ & $\begin{array}{l}\overline{19 \cdot 3} \\
23 \cdot 7 \\
19 \cdot 0 \\
23 \cdot 7 \\
16 \cdot 0 \\
23 \cdot 0 \\
30 \cdot 8 \\
25 \cdot 5 \\
- \\
-\end{array}$ & $\begin{array}{c}- \\
-\overline{24 \cdot 0 \pm 2 \cdot 3} \\
20 \cdot 8 \pm 2 \cdot 5 \\
25 \cdot 4 \pm 2 \cdot 4 \\
20 \cdot 0 \pm 1 \cdot 0 \\
25 \cdot 6 \pm 6 \cdot 0 \\
24 \cdot 2 \pm 3 \cdot 7 \\
18 \cdot 0 \pm 2 \cdot 6 \\
12 \cdot 5 \pm 3 \cdot 5 \\
9 \cdot 3 \pm 1 \cdot 0 \\
\end{array}$ & $\begin{array}{c}- \\
19 \cdot 6 \\
17 \cdot 3 \\
21 \cdot 0 \\
17 \cdot 4 \\
20 \cdot 7 \\
21 \cdot 1 \\
14 \cdot 5 \\
10 \cdot 1 \\
7 \cdot 4 \\
-\end{array}$ \\
\hline
\end{tabular}

TABLE 2

ORGAN WEIGHTS OF PALM SQUIRRELS ARRANGED AGGORDING TO REPRODUGTIVE CONDITION

\begin{tabular}{|c|c|c|c|c|c|}
\hline Condition of squirrels & $\begin{array}{c}\text { Ovary wt } \\
m g \pm S . E .\end{array}$ & $\begin{array}{l}\text { Adrenal wt } \\
m g \pm S . E .\end{array}$ & $\begin{array}{l}\text { Thyroid wt } \\
\text { mg } \pm S . E .\end{array}$ & $\begin{array}{l}\text { Uterine wt } \\
m g \pm S . E .\end{array}$ & $\begin{array}{c}\text { No. of } \\
\text { animals }\end{array}$ \\
\hline \multirow{3}{*}{$\begin{array}{l}\text { Immature and pre- } \\
\text { puberal females } \\
\text { Mature females in breed- } \\
\text { ing season } \\
\text { Pregnant females } \\
\text { Lactating females } \\
\text { Parous females in period } \\
\text { of quiescence }\end{array}$} & $7 \cdot 9 \pm 0 \cdot 3$ & $29 \cdot 2 \pm 0 \cdot 7$ & $9 \cdot 8 \pm 0 \cdot 3$ & $25 \cdot 2 \pm 4 \cdot 1$ & $84(39)$ \\
\hline & $\begin{array}{l}21 \cdot 7 \pm 0.9 \\
27 \cdot 7 \pm 0.3 \\
21.0 \pm 1.2\end{array}$ & $\begin{array}{l}41 \cdot 2 \pm 1 \cdot 8 \\
42 \cdot 3 \pm 1 \cdot 4 \\
57 \cdot 3 \pm 0 \cdot 6\end{array}$ & $\begin{array}{l}11 \cdot 1 \pm 0.4 \\
11 \cdot 2 \pm 0.4 \\
12 \cdot 6 \pm 0.5\end{array}$ & $\begin{array}{c}291 \cdot 0 \pm 30 \cdot 1 \\
232 \cdot 8 \pm 45 \cdot 5\end{array}$ & $\begin{array}{l}58(27) \\
49 \\
45(21)\end{array}$ \\
\hline & $13.8 \pm 0.7$ & $43 \cdot 7 \pm 0 \cdot 6$ & $11.6 \pm 0.5$ & $58 \cdot 6 \pm 4 \cdot 1$ & $35(25)$ \\
\hline
\end{tabular}

* Figures in parentheses indicate the number of animals for calculation of uterine weights.

following year. Squirrels born very late in the breeding season (August to September), which become sexually mature by March of the following year, appear to have a shorter period of immaturity lasting 7 months.

The period of immaturity in the palm squirrel is much shorter than that in other squirrels. In Sciurus carolinensis, $S$. niger and $S$. vulgaris, puberty is reached at about 11 to 12 months (Deanesly \& Parkes, 1933; Rowlands, 1938; Asdell, 1964). 


\section{Mature females}

Sexually mature, non-pregnant, non-lactating females are found throughout the year but are more numerous from October to February (45 to 54\%); their number decreases during the period March to September (11 to $28 \%$ ) when a large number of mature females are either pregnant or lactating (Text-fig. 1).

Mature and parous squirrels show relatively constant ovarian weights throughout the breeding season (January to August), ranging from 19 to $27 \mathrm{mg}$. The variations in ovarian weights during the breeding season are not statistically significant $(P>0 \cdot 05)$. The ovarian weights decrease sharply at the beginning of quiescence in September and range from 11 to $15 \mathrm{mg}$ till the end of December. Recrudescence of the ovary begins in January in preparation for the ensuing breeding season.



Several puberal, non-parous females examined in January had swollen vulvae and an oestrous type of vaginal smear. Follicular development was active; each ovary contained three or four fully formed Graafian follicles and several medium-sized follicles (Pl. 1, Fig. 2). Approximately $75 \%$ of all follicles, including the large Graafian follicles, showed degenerative changes in the granulosa cells. Ovulation points were seen in the ovaries of females with spermatozoa in the vaginal smear, and freshly formed corpora lutea were also present. Atretic changes were evident in the granulosa cells of most of the remaining vesicular follicles. The ovaries of oestrous squirrels showed a conspicuous, well-vascularized, secretory interstitium. Each interstitial cell was large and polyhedral with distinct boundaries. The nuclei were condensed and stained densely with haematoxylin, while the cytoplasm appeared pale and vacuolar by contrast (Pl. 2, Fig. 7). Oestrus was characterized by a fluidfilled uterus with well-developed uterine glands. The uterine stromal cells were large and oedematous. The oestrous type of vaginal smear persisted for 15 to 20 days in squirrels maintained in the laboratory. Ovulation did not occur and these females passed into a state of di-oestrus if mating was not permitted. These 
observations and the experimental evidence of induction of ovulation by gonadotrophins (Seth \& Prasad, 1967) indicate that the palm squirrel may be a reflex ovulator like the thirteen-lined ground squirrel, C. tridecemlineatus (Foster, 1934). Other species of Citellus are seasonally polyoestrous (McKeever, 1966). An interesting feature of the palm squirrel ovary is the absence of secretory or degenerating corpora lutea in the sexually active animals which are nonpregnant and non-lactating.

\section{Pregnant females}

Pregnant females are found from February until September (Text-fig. 1). There are apparently two peaks in the percentage of pregnant animals caught, the first occurring in March (51\%) and the second in July (38\%). Only rare cases of pregnancy occur in June $(6 \%)$ and in September $(5 \%)$. Mature females apparently breed twice during one breeding season.

The average number of embryos in $62 \%$ of pregnant squirrels is three and the range is from one to five. One to three corpora lutea occur in each ovary corresponding to the number of implantation sites in the respective uterine horns.

No direct evidence was obtained from the data regarding the length of gestation in palm squirrels. The earliest visible pregnancies occur in the 1st week of February. Late stages of pregnancy are found in the 1st week of March and lactating females with a recent litter also occur during this period. These observations indicate that the length of gestation may be about 30 days. Further evidence for this is provided by the following observations: (a) the two peaks of pregnancies in March and July are followed, approximately a month later, by peaks of lactating females (Text-fig. 1) and (b) female squirrels in early stages of pregnancy, caught from the wild state and maintained in the laboratory, littered after 20 to 25 days. This is similar to the observed length of gestation in other sciurids, namely 27 days in C. tridecemlineatus (Foster, 1934) and 40 days in Sciurus sp. (Asdell, 1964).

Ovarian weights of pregnant females are higher than those of mature females (Tables 1 and 2) due, presumably, to the presence of corpora lutea. Functional corpora lutea persist throughout the period of gestation. Follicular development

\section{EXPLANATION OF PLATE 1}

Figures 1 to 6 are transverse sections of ovaries of palm squirrels during different phases of reproductive activity. $\mathrm{H}$ and $\mathrm{E}, \times 72$.

FIG. 1. Ovary at autopsy on 7 to 8 months old pre-puberal squirrel in December. Early stages of follicular development are seen. Several follicles are atretic; interstitial tissue is present among the follicles.

FIc. 2. Ovary at autopsy on a non-parous mature squirrel in oestrus in January. Follicular development is active; several Graafian follicles and atretic follicles are seen. Interstitial tissue is well vascularized and appears secretory.

Fig. 3. Ovary of a squirrel in mid-pregnancy. One functional corpus luteum is seen in the section. Follicular development is active.

Fig. 4. Ovary of a lactating squirrel 2 days after parturition. All Graafian follicles are atretic and the corpora lutea are degenerating.

Frc. 5. Ovary of a squirrel in post-lactational anoestrus. Medium-sized follicles and extensive interstitial tissue are seen. There is no trace of the corpus luteum of pregnancy.

FIG. 6. Ovary during the period of quiescence (November). The ovary is characterized by the presence of medium-sized follicles and hyalinized blood vessels in the stroma; large Graafian follicles are absent. Interstitial tissue is regressed. 

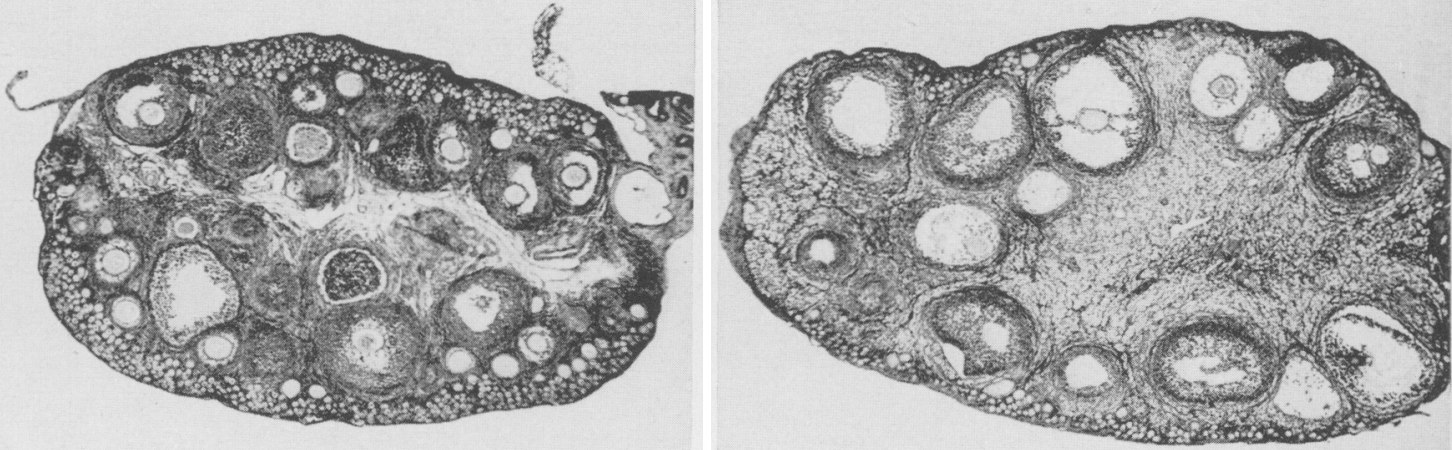

2
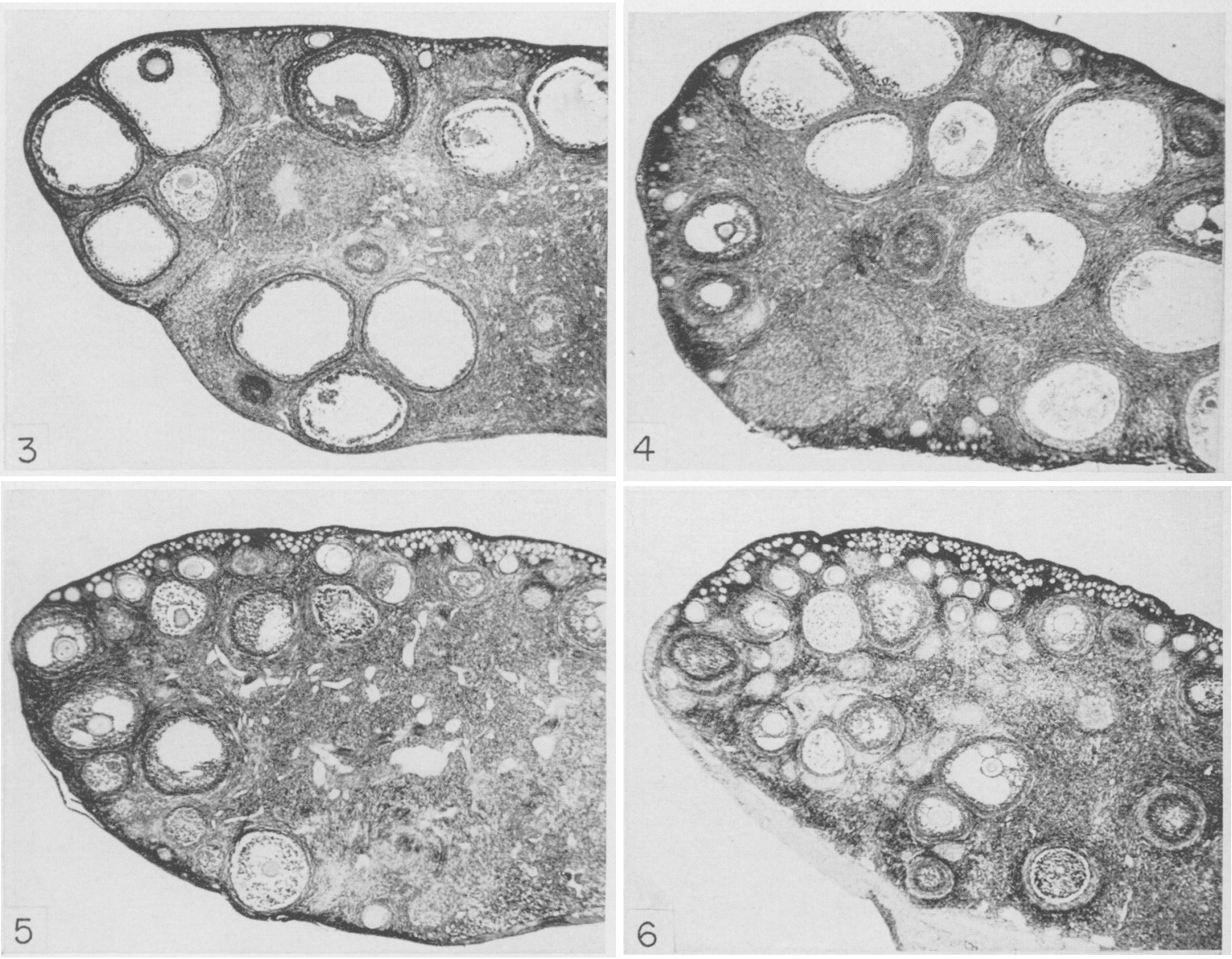

(Facing p. 216) 
PIATE 2

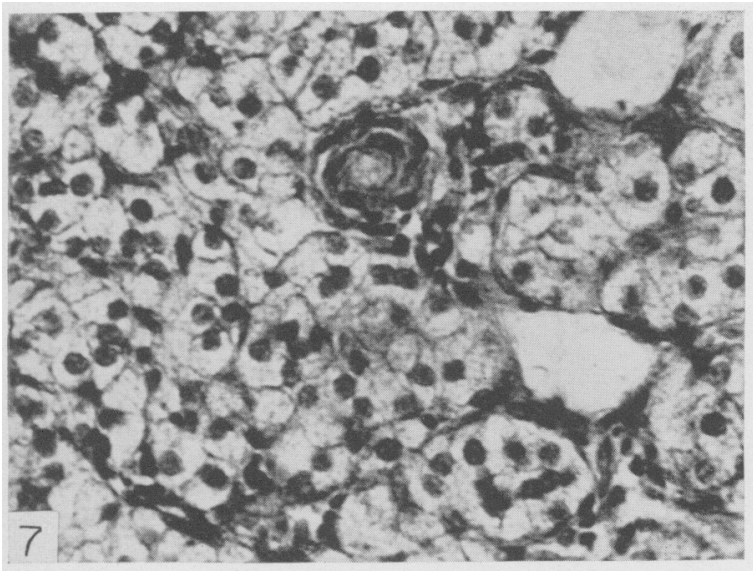

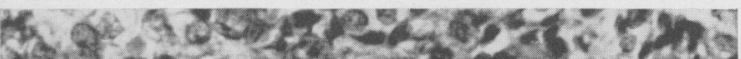

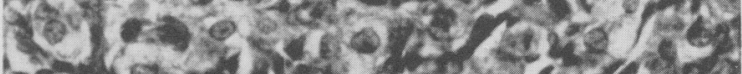

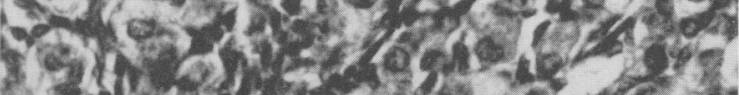

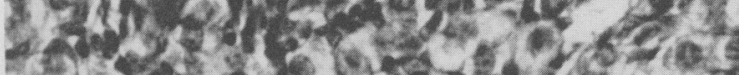

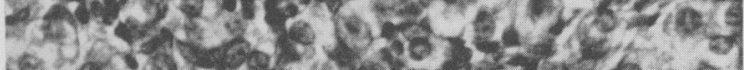

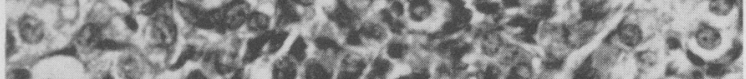

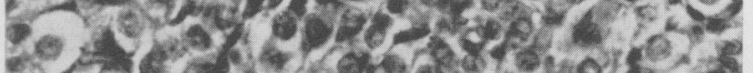

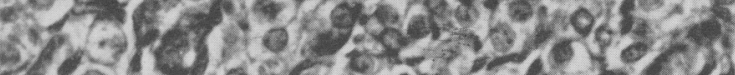

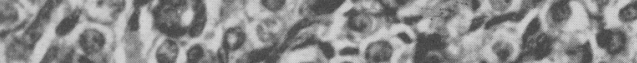

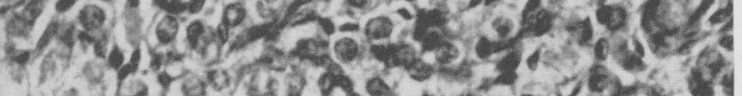

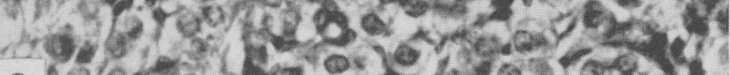

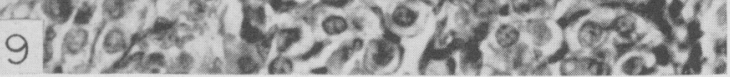

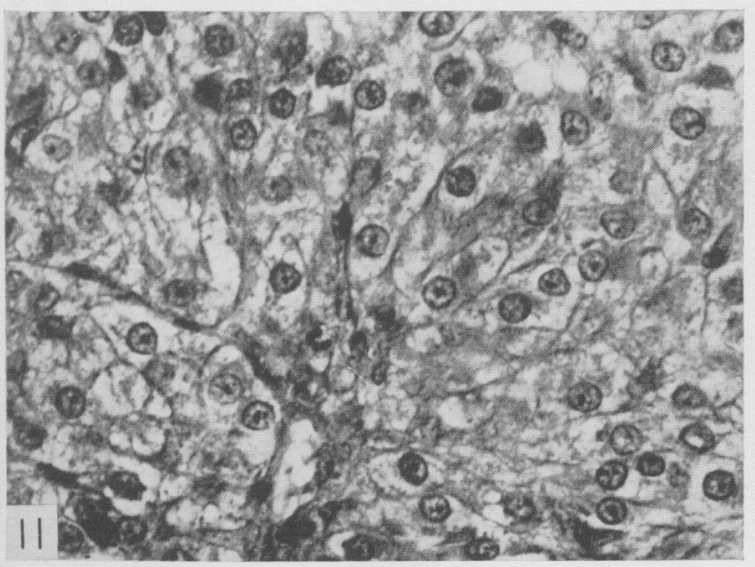

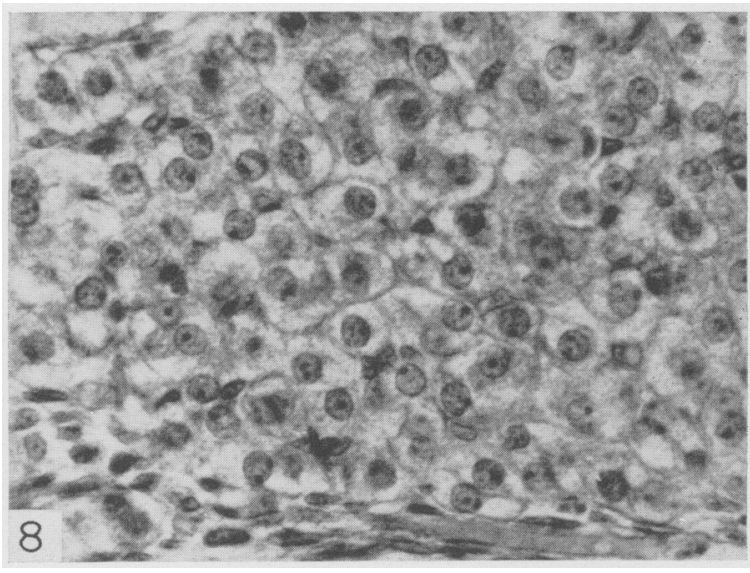

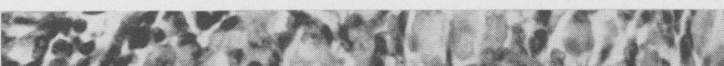

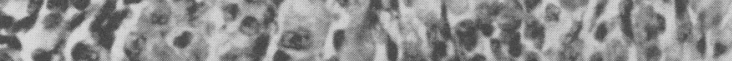

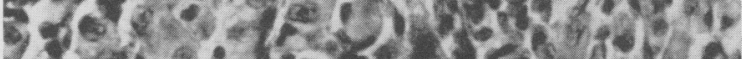

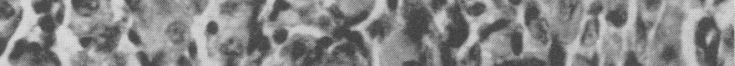
$\rightarrow$ c.

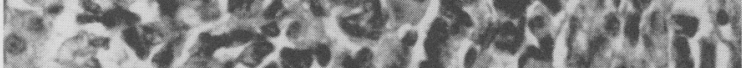

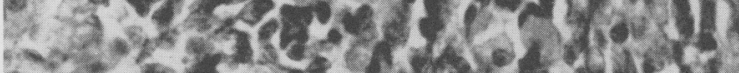

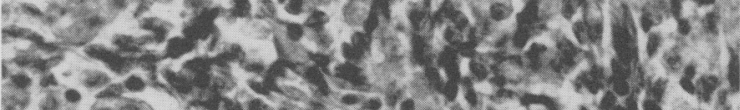
$3 e^{\circ}-20$.

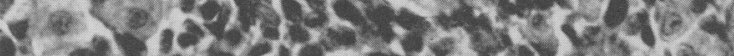

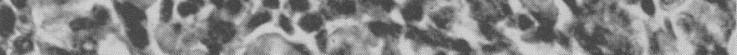

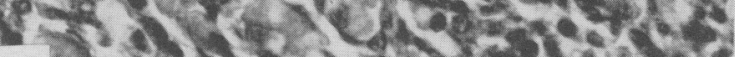

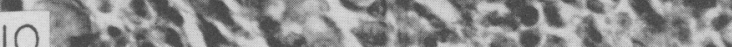

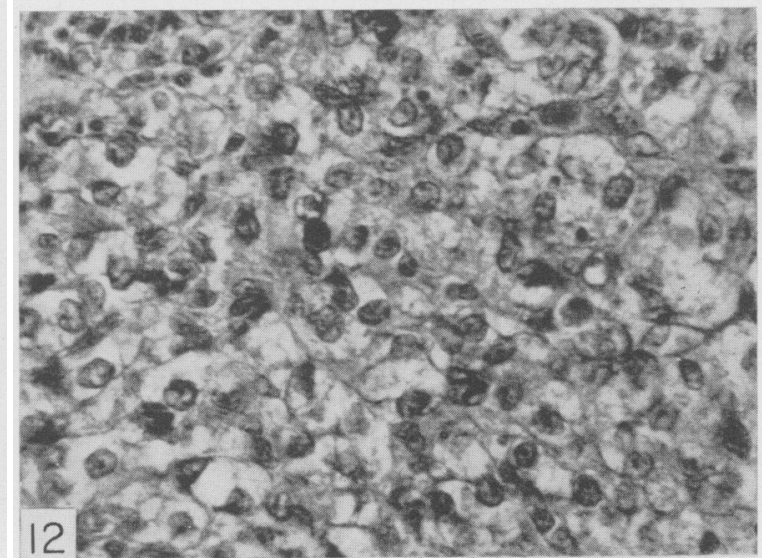


is also active during pregnancy (Pl. 1, Fig. 3) and a sudden spurt occurs during the later stages of pregnancy. A few days before parturition, ten to twelve fully developed Graafian follicles are present in the ovary along with the corpora lutea. Due to extensive follicular development, the interstitial tissue is comparatively reduced but the cells are luteal-like in appearance. The number of Graafian follicles seen during late pregnancy is many times more than that seen at oestrus. The Graafian follicles, however, do not ovulate but undergo atresia at the time of parturition, indicating that there is no post partum oestrus in the palm squirrel, $F$. pennanti.

Another interesting feature of the ovary during pregnancy is the luteinization of the small antral atretic follicles by hypertrophy of the thecal cells after the degeneration of the granulosa cells. They do not form accessory corpora lutea but become part of the interstitium of the ovary. The interstitial cells of pregnant squirrels are large with vesicular nuclei and granular cytoplasm and resemble the cells of the functional corpus luteum (Pl. 2, Figs. 8 and 11).

\section{Lactating females}

Lactating females are found from March to November. Corresponding to the occurrence of two peaks in the numbers of pregnant animals, there are two peaks in the numbers of lactating females, one in April to May (44 and $31 \%$ ) after the first peak of pregnancy in March, and the other in August $(25 \%)$ after the second peak of pregnancy in July (Text-fig. 1).

The period of lactation lasts about 6 weeks. This is indicated by the occurrence in the field during April of young squirrels apparently born in the earliest part of the breeding season and was confirmed by several observations on squirrels which littered in the laboratory and weaned their young after a similar period. Additional support comes from the fact that in a wild population of squirrels pregnancies occur until late September, while lactating females, which apparently nurse the young of these late pregnancies, are caught till early November (Text-fig. 1).

The weights of the ovaries of lactating squirrels follow a pattern similar to that of mature, non-pregnant squirrels (Tables 1 and 2). Corpora lutea of pregnancy degenerate soon after parturition. In the ovary of a lactating female at autopsy performed 2 days after parturition in the laboratory, the corpora lutea and all the follicles showed degenerative changes (Pl. 1, Fig. 4; Pl. 2, Fig. 12). Peripheral cells of the regressing corpora lutea show pigment accumulation. With the advance of lactation, these cells become a part of the interstitium and characterize the ovaries of all parous females. The interstitial cells

EXPLANATION OF PLATE 2

Fig. 7. Interstitial tissue of an oestrous squirrel. Each cell is large and polyhedral; nuclei are condensed and cytoplasm is pale and vacuolar. $\times 450$.

Frg. 8. Interstitial tissue of a pregnant squirrel. The cells have vesicular nuclei and granular cytoplasm, and resemble the luteal cells of a functional corpus luteum. $\times 450$.

Fig. 9. Interstitial tissue of a lactating squirrel. The cells are collapsed and appear nonsecretory. $\times 450$.

FIg. 10. Interstitial tissue of a quiescent squirrel. The interstitial cells are atrophic while pigment-containing cells are conspicuous. $\times 450$.

Fig. 11. Corpus luteum of pregnancy. $\times 450$.

FrG. 12. Regressing corpus luteum during early lactation 2 days after parturition. $\times 450$. 
appear collapsed and non-secretory, with only a few secretory bundles interspersed in the medulla (Pl. 2, Fig. 9). The ovary is quiescent during the period of lactation.

Within 2 days after parturition, the uterus shows regressive changes. The glands appear non-secretory and are lined by low cuboidal cells. The uterus in late lactation is similar to that of an anoestrous squirrel.

The end of lactation is followed immediately by a short period of postlactational anoestrus which may last for about 3 to 4 weeks. The ovaries of such squirrels contain medium-sized follicles and extensive, regressed interstitial tissue with no trace of degenerating corpora lutea (Pl. 1, Fig. 5). Follicular atresia of the small follicles involving pycnosis of the granulosa cells and degeneration of the oocytes is common during post-lactational anoestrus. This period is also characterized by an indeterminate type of vaginal smear, regressed mammary glands and low uterine weights. The uterine stroma is shrunken and non-oedematous.

During the breeding season, a short period of oestrus follows the termination of the post-lactational anoestrus. This marks the second oestrus of the breeding season and may lead to a second pregnancy.

\section{Quiescent females (September to December)}

Mature, parous females become sexually quiescent from the beginning of September. There is a significant decrease in ovarian weights (Tables 1 and 2). Follicular development is arrested at the stage of medium-sized follicles (Pl. 1, Fig. 6). The interstitial cells appear flattened and non-secretory. Quiescent animals are characterized by the presence of pigment-laden cells in the interstitium (Pl. 2, Fig. 10). The uterus is markedly reduced in weight (Table 2) with involuted glands and dense stroma. The appearance of the uterus is similar to that of an immature squirrel except for the large diameter due to the presence of prominent muscle layers and hyalinized blood vessels.

The changes in the thyroid and adrenal weights do not show any correlation with the reproductive cycle (Table 2).

\section{Schematic summary of the reproductive cycle in the palm squirrels}

Text-figure 2 represents schematically the growth, immaturity and reproductive cycle of $F$. pennanti. For the sake of convenience, the cycle of growth and maturity of squirrels born in the first peak of the breeding season (March) is traced from birth through suckling and growth to maturity, breeding and lactation. A similar cycle is traced for squirrels born during the second peak of pregnancy in the breeding season (July).

The squirrels born in March and weaned about 6 weeks after birth appear in the field for the first time in May. They do not breed in the year of their birth and become sexually mature by January of the following year (2nd year) after a period of immaturity of about 10 months. This is followed by oestrus and pregnancy. The squirrel which becomes pregnant early (February) during the breeding season produces its first litter in March. Suckling of the litter continues till mid-April when the female passes into a short period of anoestrus. 'This is followed by a second oestrus and pregnancy in July to August and lacta- 


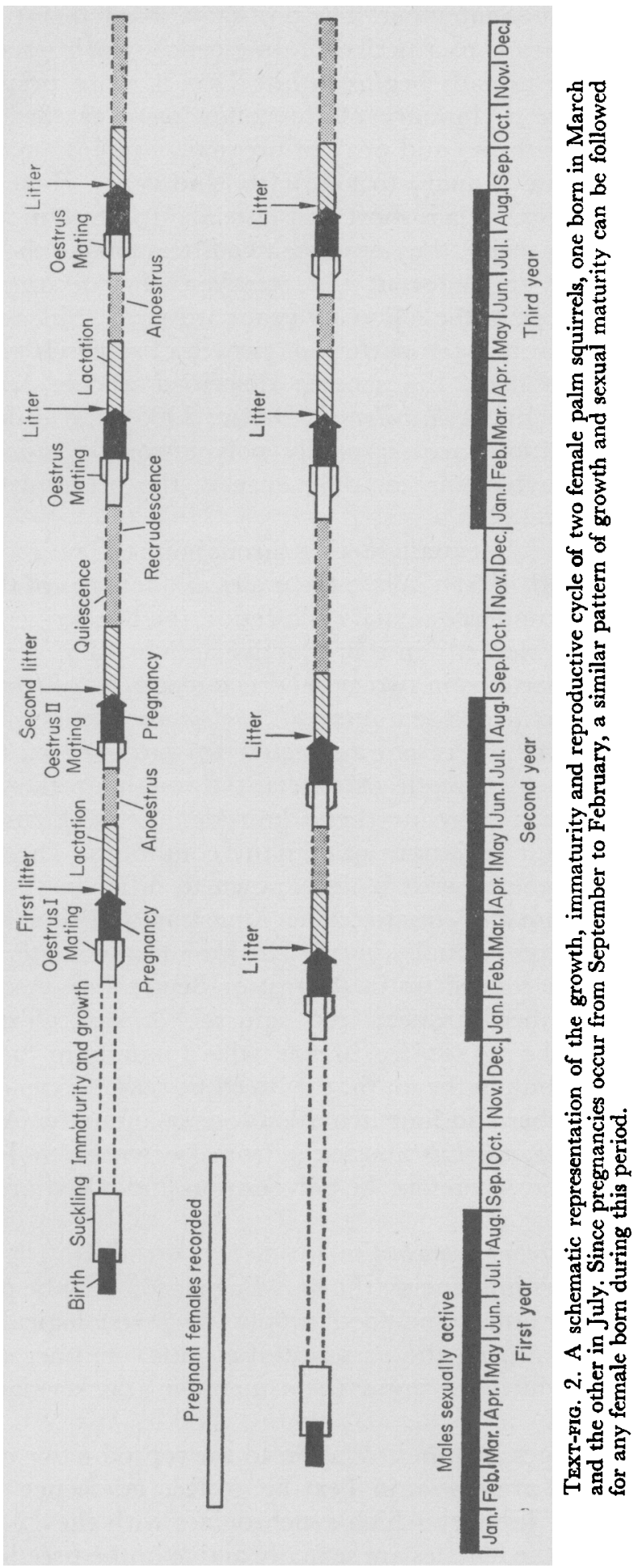


tion which may last till September. The post-lactational anoestrus at the end of the second lactation leads to a period of quiescence which lasts till December. Recrudescence of the gonads begins in late December in preparation for the next breeding season in January of the following year (3rd year). Female squirrels born during the second peak of pregnancy in July to August become sexually mature in late January to February (2nd year). Hence, the period of immaturity in these squirrels is short and lasts about 7 to 8 months. Following the onset of sexual maturity, they produce two litters during their first breeding season (2nd year) and are quiescent till December. They become reproductively active again in January of the following year (3rd year). Since young are born from March to September, the pattern of growth of squirrels born at any time during this period follows the scheme described above. Sciurus carolinensis (Deanesly \& Parkes, 1933), S. vulgaris (Delost, 1965) and different species of Citellus (McKeever, 1966) are seasonally polyoestrous. C. tridecemlineatus is a monoestrous species which breeds only once in the breeding season (Foster, 1934).

Funambulus palmarum is sexually active throughout the year; three litters are born annually (Prasad, 1951). While the males and females of the three-striped palm squirrel do not undergo sexual quiescence, the five-striped palm squirrels experience a cyclic periodicity in reproductive activity. This striking difference in the reproductive patterns in two closely related species of Funambulus may be due to their geographical distribution. F. palmarum, occurring in Bangalore $\left(77^{\circ} 38^{\prime} \mathrm{E}\right.$ and $\left.12^{\circ} 58^{\prime} \mathrm{N}\right)$, is not subjected to extremes of temperature or effective changes in the length of daylight throughout the year, while $F$. pennanti, occurring in a more northerly latitude $\left(76^{\circ} 50^{\prime} \mathrm{E}\right.$ and $\left.28^{\circ} 12^{\prime} \mathrm{N}\right)$, is subjected to significant variations of climatic conditions. The duration of the breeding season of some sciurids is also known to differ in diverse habitats at varying distances from the equator. The American red squirrel, Tamiasciurus hudsonicus, has one litter annually in May to June in the western regions, while in the east it has a second litter in August or September (Asdell, 1964). The breeding season of the European red squirrel, Sciurus vulgaris, is similarly variable. In Russia, the red squirrel breeds twice annually in January to March and in May to June, but, in the south, the breeding season extends from January till August to September and four ovulations occur annually (Asdell, 1964). In England, females of $S$. vulgaris are active from December to July (Rowlands, 1938). This species may, therefore, be polyoestrous under favourable conditions.

\section{Exteroceptive factors affecting reproduction}

The external factors influencing the breeding season may be physical, such as light, temperature, rainfall and food supply, or psychological. These factors include stimuli arising from the presence of a mate, or other social influences from the group of which the animal is a member (Zuckerman, 1952; Fraps, 1962).

The climatic changes and their relation to the reproductive cycle of the fivestriped palm squirrel are shown in Text-fig. 3. Recrudescence of the ovary begins in December to January which synchronizes with the 12 min-increase in day length. Though the females are sexually active in the breeding season when 
they are exposed to a minimum of $10 \frac{1}{2} \mathrm{hr}$ of daylight (January) or a maximum of $14 \mathrm{hr}$ of daylight (June and July), they begin to regress in August when the day length is of $13 \frac{1}{4} \mathrm{hr}$ duration. This is apparently due to ovarian refractoriness to photoperiods which were initially stimulatory. The short days in December may terminate this refractoriness. A similar condition occurs in birds (Wolfson, 1958). In $F$. pennanti, decreasing temperature and long periods of darkness in December may cause the termination of the refractoriness of the gonads to light and lead to recrudescence. Though recrudescence and regression of the ovaries can be explained on the basis of variation in the photoperiod, the occurrence of anoestrus for short periods during the breeding season bears no relation to this exteroceptive factor.

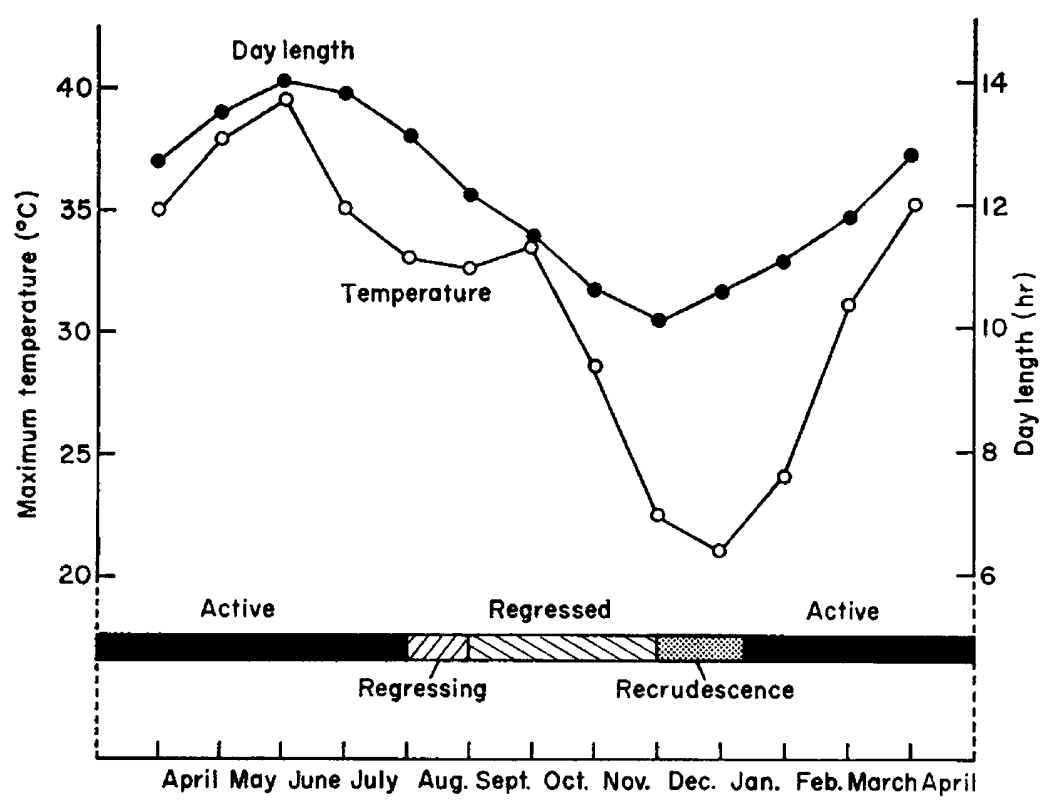

TEXT-FIG. 3. Correlation of the average monthly temperature and day length with the sexual activity of the palm squirrels.

The period of sexual activity of Citellus beecheyi and $C$. lateralis which coincides with seasonal activity are controlled by seasonally restricted food (Bartholomew \& Hudson, 1960; McKeever, 1966). F. pennanti, however, is active throughout the year and changes its diet seasonally depending on the availability of insects from February to October and of seeds from October to February (Prasad, Dhaliwal, Seth, Reddi, Sivashankar \& Uberoi, 1966). Paucity of food is apparently not a factor involved in controlling the reproductive cycle of the palm squirrel.

\section{REFERENGES}

Asdell, S. A. (1964) Patterns of mammalian reproduction, 2nd edn. Comstock, Ithaca, New York.

Bartholomew, G. A. \& Hudson, J. W. (1960) Aestivation in the Mohave ground squirrel, Citellus mohavensis. Bull. Mus. comp. Zool. Harv. 124, 193 
Deanesly, R. \& Parkes, A. S. (1933) Reproductive processes of certain mammals. IV. The oestrus cycle of the grey squirrel (Sciurus carolinensis). Phil. Trans. R. Soc. B, 222, 47.

Derost, P. (1965) The seasonal sexual cycle of the common squirrel (Sciurus vulgaris). C.r. Séanc. Soc. Biol. $159,1141$.

Foster, M. A. (1934) The reproductive cycle in the female ground squirrel Citellus tridecemlineatus (Mitchill). Am. F. Anat. 54, 487.

FraPs, R. M. (1962) Effects of external factors on the activity of the ovary. In: The Ovary, Vol. II, p. 317. Ed. S. Zuckerman. Academic Press, London.

McKeever, S. (1963) Seasonal changes in body weight, reproductive organs, pituitary, adrenal glands, thyroid gland and spleen of the belding ground squirrel (Citellus beldingi). Am. F. Anat. 113, 153 .

McKeever, S. (1966) Reproduction in Citellus beldingi and Citellus lateralis in northeastern California. Symp. zool. Soc. Lond. 15, 365.

Moore, J. G. \& TATE, G. H. H. (1965) A study of the diurnal squirrels, Sciurinae, of the Indian and Indochinese subregions. Fieldiana, Zool. 48.

Prasad, M. R. N. (1951) Changes in the reproductive organs of the male palm squirrel Funambulus palmarum Linn. Half-yly 7. Mysore Univ. 12, 89.

Prasad, M. R. N., Dhaliwal, G. K., Seth, P., Redd, A. H., Sivashankar, A. K. \& Uberoi, N. K. (1966) Biology of reproduction in the Indian palm squirrel Funambulus pennanti (Wroughton). Symp. zool. Soc. Lond. 15, 353.

RoWLANDS, I. W. (1938) Preliminary report on the reproductive cycle of the red squirrel, Sciurus vulgaris. Proc. zool. Soc. Lond. B, 108, 441.

Seth, P. \& Prasad, M. R. N. (1967) Induction of ovulation by gonadotrophins in the five-striped palm squirrel Funambulus pennanti (Wroughton). 7. Endocr. 39, 369.

Shorten, M. (1951) Some aspects of the biology of the grey squirrel (Sciurus carolinensis) in Great Britain. Proc. zool. Soc. Lond. 121, 427.

Томгсн, P. Q. (1962) The annual cycle of the California ground squirrel. Univ. Calif. Publs Zool. 65, 213.

Wolfson, A. (1958) Role of light and darkness in the regulation of the annual stimulus for spring migration and reproductive cycles. Proc. XII Int. Ornithological Congress, Helsinki, p. 758.

Zuckerman, S. (1952) The influence of environmental changes on the pituitary. Ciba Fdn Colloq. Endocr. $4,213$. 